\title{
The clinical significance of activated lymphocytes in patients with myelodysplastic syndromes: A single centre study of 131 patients
}

\author{
Stef Meers ${ }^{\mathrm{a}, \mathrm{b}, *}$, Peter Vandenberghe ${ }^{\mathrm{a}}$, Marc Boogaerts ${ }^{\mathrm{a}}$, \\ Gregor Verhoef $^{\mathrm{a}}$, Michel Delforge ${ }^{\mathrm{a}, \mathrm{b}}$ \\ a Hematology Department, University Hospital Leuven, Belgium \\ b Stem Cell Institute, University of Leuven, Belgium
}

Received 1 September 2007; received in revised form 6 October 2007; accepted 8 October 2007 Available online 19 November 2007

\begin{abstract}
We studied the immune compartment in patients with myelodysplastic syndromes. We show increased surface expression of activation markers (HLA-DR $\left.{ }^{+}, \mathrm{CD}^{+} 7^{+}, \mathrm{CD} 28^{-}, \mathrm{CD}^{2} \mathrm{~L}^{-}\right)$on T lymphocytes in blood and bone marrow $(n=131)$. T cell activation was not restricted to any relevant clinical subgroup (FAB, IPSS, cytogenetics) and did not correlate with blood counts or need for treatment. In vitro clonogenic growth of marrow mononuclear cells $(n=18)$ was not influenced by $\mathrm{T}$ cells expressing these markers. In addition, using X-chromosome inactivation analysis $(n=12)$ we demonstrate clonal involvement of NK and B cells in half of these patients. We conclude that although activated T lymphocytes can be found in MDS, their role in disease pathogenesis remains unclear in the majority of patients.

(C) 2007 Elsevier Ltd. All rights reserved.
\end{abstract}

Keywords: Myelodysplastic syndromes; Flow cytometry; T cell activation; HUMARA; Lymphocytes

\section{Introduction}

Myelodysplastic syndromes (MDS) comprise a heterogeneous group of clonal hematopoietic disorders characterized by uni-/bi- or trilineage cytopenia(s), marrow dysplasia and an increased risk of evolution to acute leukemia. The pathogenesis of marrow failure in MDS is complex and is thought to be related to a delicate interplay between intrinsic defects of the hematopoietic progenitor cells, the bone marrow (BM) microenvironment in which these progenitor cells reside, and extrinsic immune mechanisms [1]. Indeed, there is increasing evidence that immune mechanisms contribute to the process of BM failure. Autoimmune disorders frequently occur in MDS patients [2] and there is an association of MDS with closely related marrow failure disorders like aplastic anemia

\footnotetext{
* Corresponding author at: Hematology Department, University Hospital Leuven, Herestraat 49, B-3000 Leuven, Belgium. Tel.: +32 16346880 ; fax: +3216346881 .

E-mail address: stef.meers@med.kuleuven.be (S. Meers).
}

[3] and T cell large granular lymphocytic disease [4] where an immune-mediated pathogenesis has been suggested. Furthermore, clonal and oligo-clonal $\mathrm{T}$ cell expansions can be found in about half of the patients with MDS [5-10] suggesting an antigen-targeted response. In addition, these $\mathrm{T}$ cells have been shown to have an activated phenotype [10,11].

Antagonizing this immune response can improve cytopenias as is supported by numerous reports that up to $30 \%$ of low-risk MDS patients respond to immunosuppressive agents such as cyclosporine A (CsA) [3] and/or anti-thymocyte globulin (ATG) [12-15]. Good biological predictors to identify the subpopulation of patients that will respond to this kind of therapy currently lack. But, some factors such as age below 60y, HLA-DR15, low platelet counts and time to transfusion have been identified and included in predictive models [15-17].

As most reports on the immune profile of the $\mathrm{T}$ cell compartment comprehend rather small patient groups, we set up this study to determine the status of the lymphocyte 
compartment in a large group of 131 patients with MDS followed in our university hospital. For this purpose, we have quantified the number of $\mathrm{CD}^{+}$and $\mathrm{CD}^{+} \mathrm{T}$ cells, $B$ cells and NK cells in blood and BM. We also determined the clonal nature of these various subpopulations of immune cells with X-chromosome inactivation studies. In addition, we determined activation status of $\mathrm{T}$ cells in these patients with flow cytometry. These results were correlated with clinical and disease characteristics in order to identify a relevant clinical subgroup with increased or decreased prevalence of $\mathrm{T}$ cell activation. Finally, we evaluated if expression of these surface markers on $\mathrm{T}$ cells, correlated with in vitro clonogenic growth of progenitor cells.

\section{Methods and materials}

\subsection{Patients and controls}

We have analyzed peripheral blood (PB) $(n=101)$ and BM $(n=30)$ from patients with morphologically proven MDS that were treated in our institution. The mean time between sampling and time of diagnosis was 54 months (range 1-302). Samples were obtained at routine patient visits to the outpatient clinic. Sampling and handling were in accordance with the guidelines of the local ethical committee of the University Hospital of Leuven, which comply with the Helsinki declaration. In parallel, PB from 92 healthy controls was analyzed following the same protocol. The PB control group consisted of 60 predominantly young subjects (mean age 26, range 19-45). In addition, we recruited aged healthy volunteers from different social-cultural organizations in Leuven. In total 32 healthy men and women volunteered to donate blood to serve as control. The age of the control group was similar to that of the patients (mean age 67, range 50-82).

Patient characteristics are summarized in Table 1. The majority of patients was treatment naïve $(n=70)$ except for the use of supportive measures, including transfusions $(n=20)$, recombinant growth factors $(n=9)$, iron chelation therapy $(n=9)$ or a combination of these therapies. No patient received chemotherapy or cytoreductive therapy prior to analysis. Patients under immunosuppressive drugs were also excluded from this analysis, as were patients with a history of recent (within the last month) or current infection. Data on cytogenetic analysis were provided by the Centre for Human Genetics of the University Hospital of Leuven.

\subsection{Blood counts, $C$-reactive protein}

Hematological values were determined with a Sysmex XE-2100 automated Hematology Analyzer. Serum was collected at the time of sampling for the determination of serum C-reactive protein (CRP) concentrations. Serum CRP con- centration was measured on a Hitachi Modular Analytics D automated analyzer with a particle-enhanced immunoturbidimetric method (CRPLX, Roche Diagnostics).

\subsection{Flow cytometric analysis}

PB and BM samples were collected in sodium EDTA coated tubes. All samples were processed immediately. After lysis with 10:1 $\mathrm{NH}_{4} \mathrm{Cl}$ buffer and washing with phosphate buffered saline (PBS, Bio-Whittaker Europe, Cambrex, Belgium), cells were immunostained with the following fluorescein isothiocyanate (FITC), phycoerythrin (PE) and peridinin chlorophyll (PerCP) conjugated monoclonal anti-

Table 1

Clinical characteristics of patients

\begin{tabular}{|c|c|c|}
\hline & $\mathrm{PB}(n=101)$ & $\mathrm{BM}(n=30)$ \\
\hline Age (years) mean (range) & 70 (29-94) & $71(45-90)$ \\
\hline Gender (male/female) & $66 / 35$ & $17 / 13$ \\
\hline \multicolumn{3}{|l|}{ FAB } \\
\hline RA & 57 & 17 \\
\hline RARS & 33 & 8 \\
\hline RAEB & 11 & 5 \\
\hline \multicolumn{3}{|l|}{ WHO } \\
\hline RA & 1 & \\
\hline RCMD & 50 & 15 \\
\hline RARS & 1 & \\
\hline RCMD-RS & 32 & 8 \\
\hline 5q-syndrome & 5 & 1 \\
\hline RAEB-1 & 7 & 1 \\
\hline RAEB-2 & 4 & 4 \\
\hline MDS-u & 1 & 1 \\
\hline \multicolumn{3}{|l|}{ Cytogenetics } \\
\hline Normal & 45 & 11 \\
\hline Abnormal & 42 & 16 \\
\hline Good $^{\mathrm{a}}$ & 12 & 5 \\
\hline Intermediate $^{\mathrm{a}}$ & 19 & 6 \\
\hline Poor $^{\mathrm{a}}$ & 11 & 5 \\
\hline N.A. ${ }^{b}$ & 14 & 3 \\
\hline \multicolumn{3}{|l|}{ IPSS } \\
\hline Low & 39 & 8 \\
\hline Int-1 & 39 & 12 \\
\hline Int-2 & 7 & 7 \\
\hline High & 2 & \\
\hline \multicolumn{3}{|l|}{ MDS treatment } \\
\hline None & 70 & 24 \\
\hline rhEPO/rhG-CSF/both & $7 / 1 / 1$ & \\
\hline Iron chelation & 9 & \\
\hline Transfusions & 20 & 6 \\
\hline
\end{tabular}

MDS, myelodysplastic syndromes; FAB, French-American-British; RA, refractory anemia; RARS, refractory anemia with ringed sideroblasts; RAEB: refractory anemia with excess blasts; WHO: World Health Organization; RCMD, refractory cytopenia with multilineage dysplasia; RCMD-RS, refractory cytopenia with multilineage dysplasia and ringed sideroblasts; MDS-u, MDS-unclassified; IPSS, International Prognostic Scoring System.

a Good: -Y, $\operatorname{del}(5 q)$ only, $\operatorname{del}(20 q)$ only; poor: complex ( $\geq 3$ abnormalities) or chromosome 7 anomalies; intermediate: +8 , single miscellaneous abnormality or double abnormalities.

b Not available. 
bodies (MoAbs): anti-CD3, anti-CD4, anti-CD8, anti-CD19, anti-CD16/56, anti-HLA-DR, anti-CD62L, anti-CD57, antiCD28 (all from Becton Dickinson, Erembodegem, Belgium). Appropriate isotype-matched control antibodies against irrelevant antigens (Becton Dickinson, Erembodegem, Belgium) were used as negative controls. Cells were incubated with $10 \mu \mathrm{l}$ of the monoclonal antibody for $30 \mathrm{~min}$ at $4{ }^{\circ} \mathrm{C}$ in the dark, subsequently washed once with PBS and resuspended in $400 \mu$ l CellFIX (Becton Dickinson). Samples were analyzed on FACScan and FACSCanto Flow Cytometer (Becton Dickinson). Analysis of the data was performed with CELLquest and BD FACSDiva software (Becton Dickinson). Lymphocyte subsets were identified with the following MoAb panels: B cells $\left(\mathrm{CD}^{-} / \mathrm{CD} 9^{+}\right), \mathrm{CD}^{+}{ }^{+} \mathrm{T}$ cells $\left(\mathrm{CD}^{+} / \mathrm{CD}^{+}\right), \mathrm{CD}^{+}{ }^{+} \mathrm{T}$ cells $\left(\mathrm{CD}^{+} / \mathrm{CD}^{+}\right)$, and $\mathrm{NK}$ cells $\left(\mathrm{CD} 3^{-} / \mathrm{CD} 16^{+} 56^{+}\right)$.

\subsection{Clonality studies: HUMARA PCR}

Clonality of purified cell fractions was assessed by PCR amplification of polymorphic short tandem repeats of the human androgen receptor (HUMARA) gene. Cell fractions $\left(\mathrm{CD}^{+} / \mathrm{CD}^{+}, \mathrm{CD}^{+} / \mathrm{CD}^{+}, \mathrm{CD}^{-} / \mathrm{CD} 19^{+}, \mathrm{CD} 4^{+}\right.$, $\mathrm{CD}^{-} / \mathrm{CD} 16^{+} \mathrm{CD} 56^{+} / \mathrm{CD} 14^{-}$) of 12 female patients were sorted on a FACSVantage flow cytometer supplemented with Lysis II software (Becton Dickinson) and equipped with a Cell Concentrator (Becton Dickinson). Sorted cells were processed immediately. A mean of 30,000 sorted cells was used for each assay.

DNA extraction, restriction enzyme digestion and HUMARA PCR were performed as previously described [18]. Briefly, DNA was resuspended in $30 \mu \mathrm{l}$ of $\mathrm{H}_{2} \mathrm{O}$. After overnight incubation at $37^{\circ} \mathrm{C}$ with $20 \mathrm{U}$ of HpaII and $20 \mathrm{U}$ of CfoI (HhaI) (MBI Fermentas, Germany) for the digestion of unmethylated (or active) alleles, residual non-digested DNA was amplified by PCR. For PCR amplification, $2.5 \mu \mathrm{l}$ DNA template was added to $1.54 \mathrm{mM}$ $\mathrm{MgCl}_{2}, 200 \mu \mathrm{M}$ dNTP's, $12 \mathrm{pM}$ of FAM labelled primer 5'-CCG-AGG-AGC-TTT-CCA-GAA-TC-3', and primer 5' TAC-GAT-GGG-CTT-GGG-GAG-AA-3'，2.5 U Amplitaq Gold and Gene Amp buffer (Perkin-Elmer, The Netherlands) to a final reaction volume of $25 \mu \mathrm{l}$. Amplification of DNA was performed for 34 cycles $\left(30 \mathrm{~s}\right.$ at $95^{\circ} \mathrm{C}, 30 \mathrm{~s}$ at $60^{\circ} \mathrm{C}, 30 \mathrm{~s}$ at $72^{\circ} \mathrm{C}$ ) with an initial denaturation step of $10 \mathrm{~min}$ at $95^{\circ} \mathrm{C}$ and a final elongation step of $5 \mathrm{~min}$ at $72^{\circ} \mathrm{C}$. PCR products were mixed with formamide and GENESCAN 400 HC-Rox size standard (Perkin-Elmer), denatured and run automatically for $30 \mathrm{~min}$ at $15 \mathrm{kV}$ on an ABI PRISM 310 Genetic Analyzer (Perkin-Elmer) containing a Performance Optimized Polymer-4 capillar. GeneScan software (Perkin-Elmer) was used for analysis of the peak area and height of individual alleles. A corrected allelic ratio (CrR) was calculated by dividing the ratio of the predigested sample (upper/lower allele) by the ratio of the non-predigested sample. A cell fraction was considered to be clonal if the lyonization of one allele exceeded $75 \%$. This corresponded to $\mathrm{CrR}$ values of $<0.33$ and $>3$.

\subsection{Colony forming assay}

BM mononuclear cells (BMMNCs) were isolated over a Ficoll-Hypaque (Lymphoprep, Nycomed Pharma, Oslo, Norway) step gradient and washed twice in PBS. With trypan blue exclusion method $5 \times 10^{5}$ BMMNCs were enumerated and plated in MethoCult H4434 media containing $30 \% \mathrm{FBS}, 50 \mathrm{ng} \mathrm{ml}^{-1}$ stem cell factor, $10 \mathrm{ng} \mathrm{ml}^{-1}$ granulocyte-macrophage colony stimulating factor, $10 \mathrm{ng} \mathrm{ml}^{-1}$ interleukin-3, and $3 \mathrm{U} \mathrm{ml}^{-1}$ erythropoietin (StemCell Technologies, Vancouver, BC, Canada) in duplicate in 6 well-plates (Falcon Multiwell, Becton Dickinson). Following 14 days of incubation, plates were scored using an inverted microscope. On the basis of cell number and colony morphology, we defined granulocyte-monocyte colony forming units (CFU-GM), and erythroid colony forming units, either single or clustered, as burst-forming units of erythroblasts (BFU-E).

\subsection{Statistics}

All statistics was performed using Prism 3.0 software. Mann-Whitney $U$-tests were used to compare means of two populations. Spearman's tests were used to analyze covariance between two continuous variables. In order to compare differences in prevalence of categorical variables (gender, treated vs. untreated, FAB, WHO, IPSS, cytogenetic abnormalities) we needed to categorize patients and compare relative frequencies of these variables between these defined groups. Since age below 60y has been shown to predict response to immune suppressive therapy, we categorized into a group $\leq 60 \mathrm{y}$ and a group $>60 \mathrm{y}$. Patients were also grouped according to having a "high" or "low" prevalence of activated lymphocytes. Since there are no published cut-off values, the median value of expression of a specific marker was used as cut-off. We also categorized patients using the 95th percentile in the control distribution as cut-off value. Relative frequencies of categorical variables were compared using $\chi^{2}$-tests or Fisher exact-tests for low frequencies (below 5). Means between two groups were compared using Mann-Whitney $U$-tests. $p$-Values represent double-sided tests and values below 0.05 were considered significant.

\section{Results}

\subsection{Lymphocyte populations in $P B$}

With flow cytometry, we determined the number of circulating $\mathrm{CD}^{+}{ }^{+} \mathrm{T}$ cells, $\mathrm{CD} 8^{+} \mathrm{T}$ cells, $\mathrm{B}$ cells and NK cells in 101 patients with MDS. As is shown in Table 2, we demonstrated that patients have lower numbers of B cells and NK cells in $\mathrm{PB}$ compared to the 32 aged control group, whereas CD4 ${ }^{+}$ $\mathrm{T}$ cell and $\mathrm{CD} 8^{+} \mathrm{T}$ cell counts were comparable. Within the control group, we showed that young individuals had signifi- 
Table 2

Absolute numbers of immune cell populations in MDS patients

\begin{tabular}{|c|c|c|c|c|c|}
\hline & \multirow[t]{2}{*}{$n$} & \multicolumn{4}{|c|}{ Mean \pm S.E.M. $\left(\mu \mathrm{L}^{-1}\right)$} \\
\hline & & $\mathrm{CD}^{+}{ }^{+} \mathrm{T}$ & $\mathrm{CD}^{+} \mathrm{T}$ & NK & B \\
\hline \multicolumn{6}{|l|}{ Donor } \\
\hline Age controls & 32 & $680 \pm 84$ & $260 \pm 29$ & $348 \pm 32$ & $128 \pm 12$ \\
\hline \multicolumn{6}{|l|}{ MDS } \\
\hline All patients & 101 & $551 \pm 38$ & $334 \pm 38$ & $\underline{247 \pm 23^{4}}$ & $103 \pm 19^{7}$ \\
\hline \multicolumn{6}{|l|}{ MDS Subgroups } \\
\hline \multicolumn{6}{|l|}{ FAB } \\
\hline RA & 57 & $557 \pm 50$ & $347 \pm 64$ & $241 \pm 26$ & $109 \pm 17$ \\
\hline RARS & 33 & $569 \pm 67$ & $330 \pm 33$ & $266 \pm 45$ & $\underline{54 \pm 8^{8}}$ \\
\hline RAEB & 11 & $474 \pm 116$ & $282 \pm 55$ & $227 \pm 86$ & $78 \pm 38$ \\
\hline \multicolumn{6}{|l|}{ IPSS } \\
\hline Low & 39 & $539 \pm 52$ & $329 \pm 38$ & $278 \pm 44$ & $89 \pm 17$ \\
\hline Int-1 & 39 & $526 \pm 63$ & $296 \pm 36$ & $266 \pm 37$ & $94 \pm 17$ \\
\hline Int-2 & 7 & $400 \pm 139$ & $159 \pm 27$ & $\underline{177 \pm 43^{5}}$ & $53 \pm 27$ \\
\hline \multicolumn{6}{|l|}{ Gender } \\
\hline Male & 66 & $528 \pm 46$ & $356 \pm 54$ & $256 \pm 27$ & $84 \pm 12$ \\
\hline Female & 35 & $602 \pm 63$ & $310 \pm 38$ & $244 \pm 44$ & $92 \pm 20$ \\
\hline \multicolumn{6}{|l|}{ Cytogenetics } \\
\hline Normal & 45 & $567 \pm 49$ & $365 \pm 38$ & $313 \pm 40$ & $88 \pm 15$ \\
\hline Good $^{\mathrm{a}}$ & 12 & $557 \pm 149$ & $214 \pm 40^{2}$ & $180 \pm 36$ & $109 \pm 32$ \\
\hline Intermediate $^{\mathrm{a}}$ & 19 & $486 \pm 82$ & $\overline{263 \pm 42}$ & $239 \pm 51$ & $87 \pm 27$ \\
\hline Poor $^{\mathrm{a}}$ & 11 & $\underline{299 \pm 55^{1}}$ & $\underline{217 \pm 49^{3}}$ & $\underline{130 \pm 27^{6}}$ & $65 \pm 25$ \\
\hline \multicolumn{6}{|l|}{ MDS-treatment } \\
\hline No & 70 & $559 \pm 43$ & $342 \pm 49$ & $237 \pm 26$ & $99 \pm 14$ \\
\hline Transfusions & 20 & $637 \pm 113$ & $265 \pm 40$ & $226 \pm 49$ & $62 \pm 12$ \\
\hline Other & 11 & $454 \pm 99$ & $390 \pm 112$ & $344 \pm 98$ & $43 \pm 15$ \\
\hline
\end{tabular}

Results of PB of 101 patients and 32 age controls. MDS, myelodysplastic syndromes; FAB, French-American-British; RA, refractory anemia; RARS, refractory anemia with ringed sideroblasts; RAEB: refractory anemia with excess blasts; IPSS, International Prognostic Scoring System; NK: natural killer cell; S.E.M.: standard error of the mean; $p$-value represent two-sided Mann-Whitney $U$-tests, $p$-values $<0.05$ were considered significant and are: ${ }^{1}$ poor vs. normal, $p=0.02$; ${ }^{2}$ good vs. normal, $p=0.04 ;{ }^{3}$ poor vs. normal, $p=0.02 ;{ }^{4}$ donor vs. MDS, $p=0.0008 ;{ }^{5}$ Int- 2 vs. low, $p=0.02 ;{ }^{6}$ poor vs. normal, $p=0.008 ;{ }^{7}$ donor vs. MDS, $p=0.0003 ;{ }^{8}$ RARS vs. RA, $p=0.02$.

${ }^{\text {a }}$ Good: $-Y$, del(5q) only, del( 20 q) only; poor: complex ( $\geq 3$ abnormalities) or chromosome 7 anomalies; intermediate: +8 , single miscellaneous abnormality or double abnormalities.

cantly more $\mathrm{PB} \mathrm{CD} 4^{+} \mathrm{T}$ cell and $\mathrm{CD} 8^{+} \mathrm{T}$ cells than the aged controls. NK and B cell numbers did not differ between age groups.

\subsection{Correlation of lymphocyte population numbers with clinical characteristics}

We compared the PB numbers of these cell populations between different clinical subgroups (results are summarized in Table 2). We found that patients with RARS have significantly lower numbers of circulating $B$ cells than patients with RA. We found no differences between subgroups with different IPSS score, nor between males and females. Intriguingly, patients with poor cytogenetic risk score have significantly lower numbers of $\mathrm{CD}^{+} \mathrm{T}$ cells, $\mathrm{CD}^{+} \mathrm{T}$ cells and $\mathrm{NK}$ cells than patients with normal cytogenetics. We did not demonstrate correlations between these PB cell populations and hemoglobin concentrations, neutrophil or platelet counts. Although differences in kinetics could account for the absence of covariance, it is suggestive that cytopenias in myeloid lineages do not coincide with decreased numbers of lymphocytes or NK cells.

\subsection{Clonality of purified PB lymphoid populations}

The clonal involvement of different purified populations was determined with the HUMARA assay. X-chromosome inactivation analysis is based on the concept that early in embryonic development, one of both X-chromosomes in each female somatic cell becomes randomly inactivated [19]. In normal conditions, the ratio of inactivated X-chromosomes follows a binomial distribution. The first exon of the human androgen receptor (HUMARA) gene, located on the long arm of the X-chromosome contains a polymorphic CAG repeat. In females heterozygous for the number of CAG repeats, PCR amplification of this region leads to two PCR products of different size. Excessive lyonisation or skewing is a hallmark of monoclonal cell population, and is detected with HUMARA by unequal distribution of the two PCR products. Fig. 1A represents the results of the HUMARA 
(A)
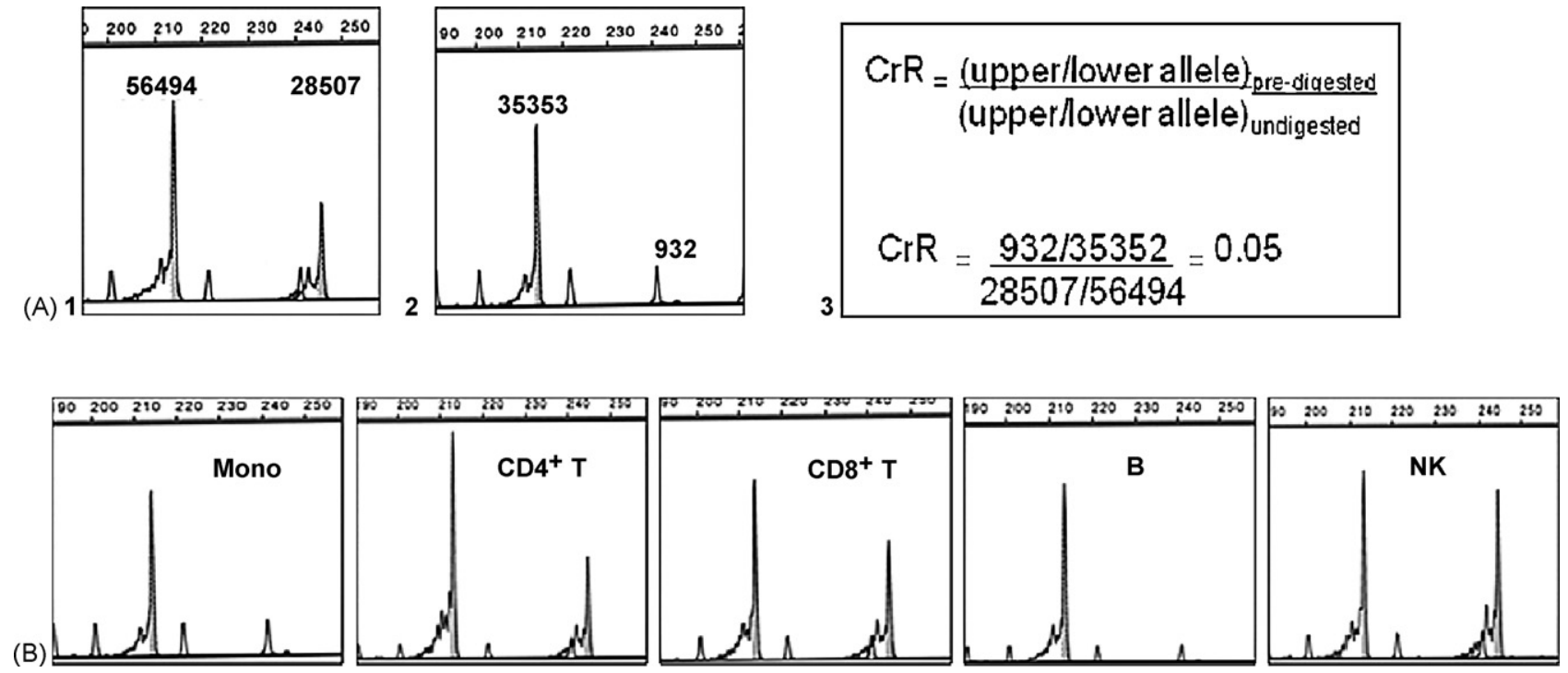

Fig. 1. HUMARA assay on purified PB populations represents HUMARA assay of purified PB populations of patient \#12 from Table 4. A(1) Amplification of undigested DNA reveals two PCR products on capillary gel electrophoresis, indicating the patient is heterozygous for the number of CAG repeats. Numbers represent the area under the curve of each peak. A(2) Following digestion of unmethylated alleles, PCR amplification reveals that one allele is preferentially inactivated. A(3) Calculation of corrected allelic ratio, which accounts for the preferential amplification of the shorter PCR product. (B) Plots of the different PB populations after digestion and PCR amplification, indicating clonal populations of monocytes and B cells, but polyclonal populations of NK, CD4 ${ }^{+} \mathrm{T}$ and CD8 ${ }^{+} \mathrm{T}$ cells.

assay on purified $\mathrm{CD} 14^{+}$monocytes of patient \#12. PCR amplification of undigested samples demonstrates that the patient is heterozygous for the number of CAG repeats in the first exon of the HUMARA-gene. It can be appreciated that following digestion of unmethylated (active) alleles, the monocyte population is shown to be predominantly of clonal origin. For interpretation, we use the corrected allelic ratio $(\mathrm{CrR})$, which compensates for the preferential amplification of the shorter allele. $\mathrm{CrR}<0.33$ or $>3$ are considered to represent clonal populations (i.e. $>75 \%$ ). Fig. 1B represents the different purified populations from patient \#12 that were analyzed.

As is summarized in Table 3, we showed that the myeloid fraction was monoclonal in all cases. $\mathrm{T}$ cells were predomi- nantly polyclonal in all patients, except for a 78y patient (case \#10) who had clonal $\mathrm{CD}^{+}{ }^{+} \mathrm{T}$ cell and $\mathrm{CD}^{+} \mathrm{T}$ cell populations. In addition, one other patient had clonal $\mathrm{CD} 8^{+} \mathrm{T}$ cells. In contrast, we showed clonal B and NK cells in half of the analyzed patients.

\subsection{Lymphocyte activation markers in MDS}

Upon activation, lymphocytes express the markers HLADR and CD57, whereas they lose expression of CD62L and CD28 [20]. We determined the percentage of lymphocytes expressing these markers (see Fig. 2). In contrast with the absolute numbers of circulating T cells, B cells and NK cells, the expression of lymphocyte activation markers was inde-

Table 3

HUMARA assay on purified population from PB of 12 female MDS patients

\begin{tabular}{|c|c|c|c|c|c|c|c|c|}
\hline \multirow[t]{2}{*}{ Case } & \multirow[t]{2}{*}{ Age } & \multirow[t]{2}{*}{ FAB } & \multirow[t]{2}{*}{ Cytogenetics } & \multicolumn{5}{|c|}{ CrR of purified populations } \\
\hline & & & & Monocytes & $\mathrm{CD}^{+}{ }^{+} \mathrm{T}$ & $\mathrm{CD}^{+} \mathrm{T}$ & B & NK \\
\hline 1 & 60 & RARS & $46, X X, \operatorname{del}(11)(\mathrm{q} 21)$ & 27.70 & 0.60 & 0.82 & 0.49 & 0.35 \\
\hline 2 & 64 & RARS & $46, \mathrm{XX}$ & $\overline{129.15}$ & 0.45 & 0.72 & 4.64 & $\underline{90.17}$ \\
\hline 3 & 74 & RARS & $46, X X, \operatorname{del}(13)(q 13 q 21)$ & $\underline{0.00}$ & 0.36 & 0.36 & $\overline{0.42}$ & $\overline{0.00}$ \\
\hline 4 & 59 & RA & $46, \mathrm{XX}, \operatorname{del}(5)(\mathrm{q} 14 \mathrm{q} 33)$ & $\overline{0.29}$ & 0.67 & 0.68 & 0.36 & $\overline{0.63}$ \\
\hline 5 & 74 & RA & $47, \mathrm{XX}, \operatorname{del}(5)(\mathrm{q} 13 \mathrm{q} 34),+8$ & 23.62 & 1.62 & 1.18 & 1.92 & $\underline{4.27}$ \\
\hline 6 & 73 & RA & $46, \mathrm{XX}$ & $\overline{0.15}$ & 0.65 & 1.62 & $\underline{0.19}$ & $\overline{0.10}$ \\
\hline 7 & 78 & RAEB & $46, X X$ & $\overline{3.01}$ & 2.89 & 4.48 & $\overline{3.31}$ & $\overline{2.95}$ \\
\hline 8 & 75 & RA & $46, \mathrm{XX}$ & $1 \overline{4.05}$ & 1.12 & $\overline{1.24}$ & $\overline{2.36}$ & 45.80 \\
\hline 9 & 62 & RA & $46, X X, \operatorname{del}(5)(q 31)$ & $\overline{0.01}$ & 2.36 & 2.36 & 0.50 & $\overline{1.24}$ \\
\hline 10 & 73 & RARS & $46, X X, \operatorname{del}(13)(q 13 q 21)$ & $\overline{0.00}$ & 0.19 & 0.19 & $\underline{0.31}$ & 0.35 \\
\hline 11 & 74 & RAEB & $46, X X$ & $9 \overline{3.87}$ & $\overline{0.70}$ & $\overline{0.70}$ & $2 \overline{21.59}$ & 9.46 \\
\hline 12 & 59 & RA & $47, \mathrm{XX},+8$ & 0.05 & 0.81 & 0.81 & 0.02 & 1.26 \\
\hline
\end{tabular}

Results of clonality study on 12 patients using HUMARA assay on purified cell subpopulations from peripheral blood. Population was regarded as clonal with corrected allelic ratio $(\mathrm{CrR})$ value of $<0.33$ or $>3$. Clonal populations are underlined in the table. 

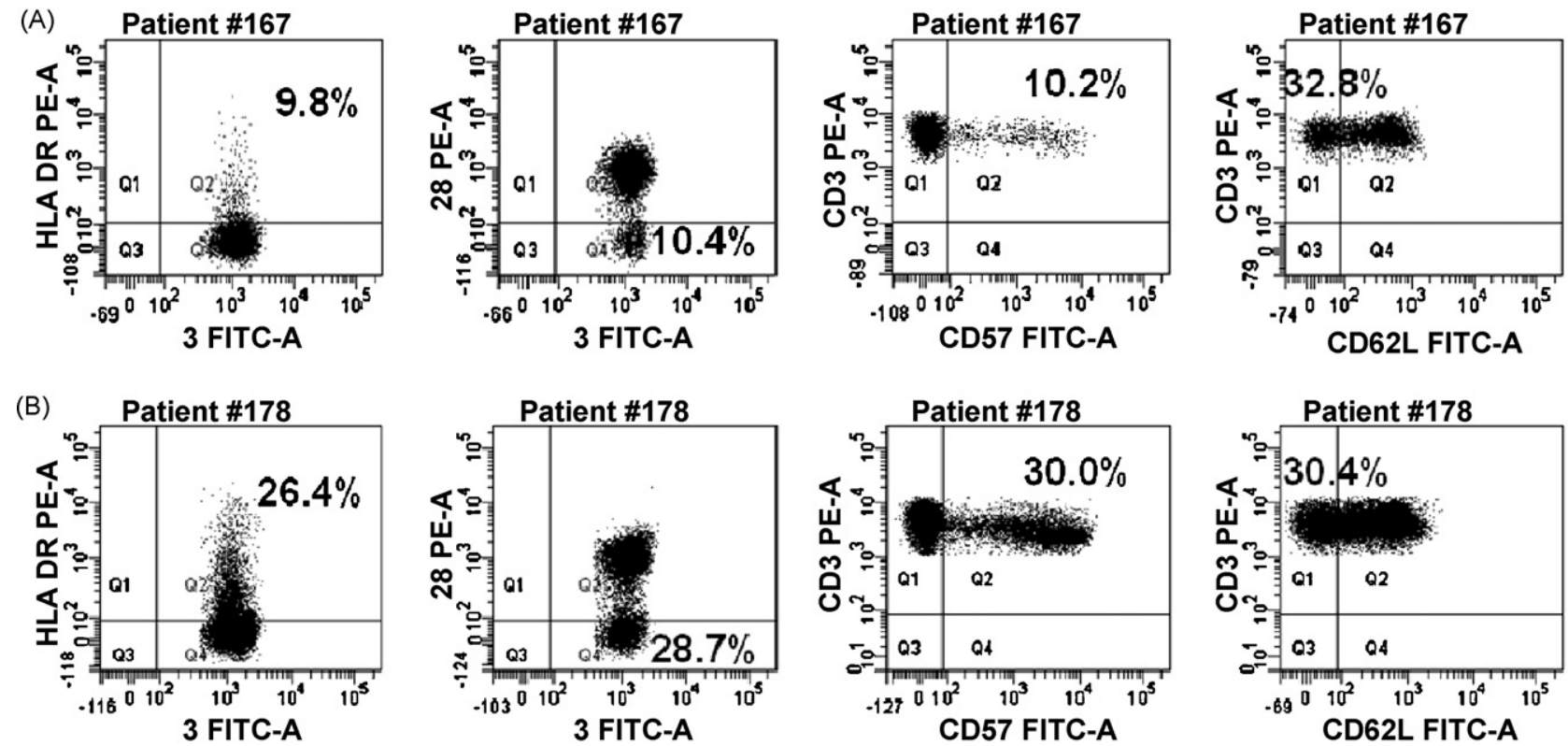

Fig. 2. Flow cytometric analysis of expression of activation markers by PB T cells, (A) represents a 55y female patient with RAEB-2 with abnormal karyotype (46,XX,5q-,11q-) with low expression of activation markers on circulating lymphocytes; (B) represents a 51y male patient with RAEB-1 with complex karyotype with high expression of activation markers on circulating lymphocytes.

pendent of age (data not shown), and therefore all 92 control samples were used to serve as control. We found that patients have significantly more activated lymphocytes in PB (see Table 4). Increased expression of CD57 and HLA-DR and loss of CD28 and CD62L expression correlated highly significantly ( $p<0.0001$ for all variables inter-individually). In the BM samples of patients, we found comparable expression levels of activation markers by $\mathrm{T}$ cells as the levels found in PB of MDS patients: HLA-DR ${ }^{+}(27.7 \pm 2.9 \%)$, $\mathrm{CD} 28^{-}(27.7 \pm 3.9 \%), \mathrm{CD}^{-} 7^{+}(20.1 \pm 3.8 \%)$ and $\mathrm{CD}^{-} \mathrm{L}^{-}$ $(43.8 \pm 5.3 \%)$.

\subsection{Correlation of lymphocyte activation markers with clinical characteristics}

The percentage of lymphocytes with an activated phenotype did not differ between FAB or WHO subgroups. Furthermore, IPSS risk score, BM blast count or disease duration had no influence on expression of activation markers by lymphocytes, nor did the presence of abnormal cytogenetics. Surprisingly, we found that only gender had an influence on our results as males had significantly higher percentage of HLA-DR ${ }^{+}(20.2 \pm 1.4$ vs. $15.4 \pm 1.7 \%, p=0.01)$ and $\mathrm{CD} 28^{-}(22.6 \pm 1.0$ vs. $16.1 \pm 2.3 \%, p=0.03) \mathrm{T}$ cells. Also in the control group, males had higher percentages of HLA-DR ${ }^{+}$and CD28- ${ }^{-}$cells, but this was not significant (data not shown). We did not observe any correlation between the presence of activation markers and blood counts in any defined clinical subgroup. Nor was there a correlation between expression of the above-mentioned markers and serum CRP levels. We found that the number of $\mathrm{CD}^{+}$ cells significantly correlated with the percentage of CD28 ${ }^{-}$, $\mathrm{CD} 7^{+}$and $\mathrm{CD} 62 \mathrm{~L}^{-} \mathrm{T}$ cells $(r=0.30, p<0.005 ; r=0.33$, $p<0.01 ; r=0.37, p<0.005$, respectively). The correlation with the percentage of HLA-DR ${ }^{+} \mathrm{T}$ cells with $\mathrm{CD} 8^{+} \mathrm{T}$ cell numbers was not significant.

Finally, we categorized our patient population into relevant groups in order to compare relative frequencies of categorical variables in these groups (e.g. FAB, WHO, IPSS, recurrent cytogenetic abnormalities, treatment). We compared patients younger and older than $60 \mathrm{y}$ and patients with "high" and "low" levels of T cell activation (as described in Section 2). However, there were no disease characteristics

Table 4

Surface expression of activation markers on PB T cells

\begin{tabular}{|c|c|c|}
\hline & \multicolumn{2}{|c|}{ PERIPHERAL BLOOD } \\
\hline & Mean \pm S.E.M. $(\%)$ & $p$-Value \\
\hline \multicolumn{3}{|l|}{ HLA-DR $^{+}$} \\
\hline Control & $9.9 \pm 0.5$ & \\
\hline MDS & $18.7 \pm 1.1$ & $<0.0001$ \\
\hline \multicolumn{3}{|l|}{$\mathrm{CD} 28^{-}$} \\
\hline Control & $11.0 \pm 0.9$ & \\
\hline MDS & $20.2 \pm 1.5$ & $<0.0001$ \\
\hline \multicolumn{3}{|l|}{$\mathrm{CD}_{57^{+}}$} \\
\hline Control & $6.2 \pm 0.6$ & \\
\hline MDS & $18.0 \pm 1.6$ & $<0.0001$ \\
\hline \multicolumn{3}{|l|}{$\mathrm{CD} 2 \mathrm{~L}^{-}$} \\
\hline Control & $26.4 \pm 1.3$ & \\
\hline MDS & $43.3 \pm 2.2$ & $<0.0001$ \\
\hline
\end{tabular}

PB results comprehend 101 patients and 92 controls. S.E.M.: standard error of the mean; $p$-values represent two-sided Mann-Whitney $U$-tests. 
that were consistently over-represented in a specific group. The only consistent finding was a significantly higher number of $\mathrm{CD}^{+} \mathrm{T}$ cells in patients with high prevalence of lymphocyte activation.

\subsection{In vitro effects of activated lymphocytes}

It has been shown that the suppressive role of $\mathrm{CD} 8^{+} \mathrm{T}$ cells is restricted to the clonal cell populations within the $\mathrm{CD} 8^{+} \mathrm{T}$ cell pool [8]. In addition, it was shown that these clonal T cells have an activated phenotype [10]. It is however not known if the expression of these activation markers relates to the suppressive properties of $\mathrm{T}$ cells. In order to evaluate this, we cultured $5 \times 10^{5} \mathrm{BM}$ mononuclear cells of 18 patients in a standard clonogenic assay. Patients were categorized as RA $(n=11)$, RARS $(n=4)$ and RAEB $(n=3)$ according to FAB and as RCMD $(n=9)$, RA $(n=1), 5 \mathrm{q}$-syndrome $(n=1)$, RCMD-RS $(n=4)$, RAEB-1 $(n=2)$ and RAEB-2 $(n=1)$ according to WHO. After 14 days, hematopoietic colonies were scored. The median number of CFU-GM was 35 (range 8-260) and the median number of BFU-E was 14 (range 0-155). In order to evaluate the influence of activated $\mathrm{T}$ lymphocytes on in vitro myelopoiesis, we correlated the numbers of colonies scored, with the percentage of activated lymphocytes in the BM sample from which BMMNC were cultured. We found that the number of colonies formed was highly variable amongst MDS patients. We were unable to demonstrate a correlation between the expression of any of the activation markers and the numbers of colonies grown in vitro. We were also unable to demonstrate that the number of $\mathrm{CD}^{+} \mathrm{T}$ cells or $\mathrm{CD} 8^{+} \mathrm{T}$ cells influenced colony growth.

\section{Discussion}

Nowadays it has become generally accepted that the immune system plays an important role in the pathogenesis and clinical presentation of MDS. Quantitative and functional anomalies have been reported since more than two decades and reported anomalies can affect both $T$ cell and B cell compartment [21-23]. It is still a matter of debate if these reported changes in the lymphoid compartment in MDS patients are only secondary phenomena evoked by the presence of a clonal progenitor pool, or if they exert a pathogenic role and contribute to marrow failure in MDS. The latter hypothesis seems supported by reports on inhibition of erythroid and myeloid progenitor growth by autologous $\mathrm{T}$ cells $[5,24]$ and the hematological response in about one-third of low-risk patients treated with immunosuppressive agents like CsA and ATG [3,25-27]. Most evidence to date is suggesting that the myelosuppressive activity of autologous $\mathrm{T}$ cells resides in the $\mathrm{CD} 8^{+} \mathrm{T}$ cell pool $[8,11]$. If autologous $\mathrm{T}$ cells participate in the process of marrow failure, one could presume that this is reflected in phenotypic or numeric changes in the $\mathrm{T}$ cell compartment. This study was designed to determine the phe- notype and number of immune cells in a large group of MDS patients.

In contrast to previous reports demonstrating lymphopenia in MDS patients, we show that the numbers of PB CD4 ${ }^{+}$ $\mathrm{T}$ cells and $\mathrm{CD}^{+}{ }^{+} \mathrm{T}$ cells in patients are not significantly different from healthy controls of the same age-group. Age was found to have a major influence on $\mathrm{CD}^{+} \mathrm{T}$ cell and $\mathrm{CD}^{+} \mathrm{T}$ cell counts in our control population. Other authors have reported reduced numbers of $\mathrm{CD} 4^{+} \mathrm{T}$ cells and increased $\mathrm{CD} 8^{+} \mathrm{T}$ cell counts, but differences in control groups ("adult" donors [21]) and patient groups (30 of 36 patients were of the more advanced RAEB subgroup [22]) could account for these apparent differences. Our finding of low $\mathrm{CD}^{+} \mathrm{T}$ cells in intermediate-2 risk patients for instance is probably in line with Colombat et al.'s [22] observations, as most of the patients in that particular population would have had a higher IPSS score. The same observation was made by Amin [28], who demonstrated that "high" risk MDS patients (RAEB-T, CMML) had lower T cell numbers. Of note, we demonstrated that patients with poor cytogenetic risk score had significantly lower $\mathrm{CD}^{+}$and $\mathrm{CD} 8^{+} \mathrm{T}$ cell counts than patients with normal cytogenetics. In agreement with previously published results, T cells were found to be polyclonal in the vast majority of the 12 patients we analyzed. Only two patients were found to have skewed lyonization in the $\mathrm{CD} 4^{+} \mathrm{T}$ cell and $\mathrm{CD} 8^{+} \mathrm{T}$ cell population. Skewed hematopoiesis has been shown to spontaneously occur in aging women [29]. Since the allelic ratio was borderline in all cell fractions of these two patients, this phenomenon could have been responsible for the finding of clonal $\mathrm{CD}^{+} \mathrm{T}$ cell and $\mathrm{CD} 8^{+} \mathrm{T}$ cell populations in the two patients. Previous reports demonstrate clonal [30-34] as well as polyclonal [35-37] T cells in MDS patients. However, there are several caveats in interpreting results from clonality assays regarding lymphocytes. Firstly, the transformation event in MDS may be incompatible with further lymphoid differentiation and if so, the lymphocytes in patients with MDS may be derived from residual normal hematopoietic stem cells or long-lived lymphoid progenitor cells $[38,39]$. In addition, polyclonal PB lymphocytes do not exclude the presence of a minor monoclonal lymphoid population.

Humoral immunity in aged individuals is severely compromised as a result of (1) decreased production of $B$ lymphocytes because of intrinsic and microenvironmental defects and (2) a disrupted germinal centre formation due altered T cell/B cell interactions [40]. Notwithstanding this age-related effect, MDS patients have even lower B cell counts (cf. Table 2) which is consistent with previous reports $[28,41]$. Intriguingly, RARS patients had even lower B cell numbers than RA patients. Reduced numbers can be related to impaired production or to increased apoptosis and supportive data for both have been published. Amin reported a higher apoptotic rate (Annexin V-positive) in the $\mathrm{CD} 19^{+}$population of patients [28]. Sternberg demonstrated that patients have reduced numbers of B-cell progenitors and in a gene expression array, patients have found to have marked reduced 
expression of B-affiliated genes [41]. We demonstrate clonal involvement of B cells in half of our patients. Although clonal involvement is an attractive explanation for decreased numbers of $\mathrm{B}$ cells, we did not see different $\mathrm{B}$ cell numbers between patients with clonal and polyclonal B cell populations (data not shown).

NK cells are critical in host defense against malignant transformation and are potent antileukemic cytotoxic effectors. Their antileukemic potential has been demonstrated in AML patients, where NK cell activity positively correlated with relapse-free survival in patients in complete remission [42]. In normal individuals, it is regarded that the number of NK cells significantly increases with age [43] whereas NK cell function, both cytotoxicity and cytokine production, is impaired in old individuals. In MDS, numerical and functional differences have been described. In contrast with previous reports [44-46], we demonstrate a decreased NK cell number in PB of patients and this was more pronounced in patients with poor cytogenetic risk score. It is however not possible from this data to speculate if these low numbers contribute to the worse prognosis patients with poor cytogenetic risk. Surprisingly, we found that the number of NK cells decreased with increasing CRP levels, but any causal relationship remains elusive. We determined clonal involvement of NK cells, and found a high prevalence of clonal NK cells using the HUMARA assay (6/12). NK cells are usually found to be polyclonal in most patients [45], but there have been reports of clonal involvement [46-48]. Although the number of patients was relatively low, we did not find that clonal involvement of NK cells led to lower overall NK cell numbers (data not shown).

The other aim of this project was to evaluate the clinical significance of activated T cells in patients with MDS. We here confirm in this large patient group that $\mathrm{T}$ cells have an activated phenotype. To the best of our knowledge, we are the first to demonstrate that lymphocytes are also activated in the BM, where they are supposed to exert their action. It was shown previously that in about half of the patients with MDS, clonal $\mathrm{T}$ cell expansions can be demonstrated [5,7-10]. It was shown that the myelosuppressive activity of $\mathrm{T}$ cells is restricted to these clones [8] and that these clonal $\mathrm{T}$ cells have an activated phenotype [10,11]. Since clonotyping of $\mathrm{T}$ cell receptor repertoire is a time-consuming technique, determining the activation phenotype of PB T cells would be a meaningful alternative method to detect patients with a suspected immune-mediated disease. However, our observations do not fully support this.

In favor of the use of $\mathrm{T}$ cell immunophenotyping is the fact that we did not find a correlation between expression of the above-mentioned markers and serum CRP levels. This suggests that the presence of activated $\mathrm{T}$ cells does not just merely reflect a systemic inflammatory state. In addition, we found that the number of $\mathrm{CD}^{+} \mathrm{T}$ cells increased with increasing expression of $\mathrm{T}$ cell activation markers. Although we did not determine the expression of these markers on $\mathrm{CD}^{+} \mathrm{T}$ cells and $\mathrm{CD}^{+} \mathrm{T}$ cells separately, this is in line with pre- vious reports that $\mathrm{CD} 8^{+} \mathrm{T}$ cells have an effector phenotype $[10,11]$.

We were unable to demonstrate that lymphocyte activation is restricted to a specific FAB or WHO subgroup or to patients with a specific IPSS score or specific karyotypic abnormality. We could not show that the presence of activated lymphocytes altered clinical phenotype of patients, as blood counts and need for supportive care were comparable between patients with high and low percentage of lymphocyte activation. Recently, Epling-Burnette et al. compared clinical characteristics of patients with and without clonal $\mathrm{T}$ cell expansions [10]. They were also unable to demonstrate that the presence of these clones is restricted to a relevant clinical subgroup.

Much of what is known about immune mediated marrow failure in MDS has been established in trisomy 8 MDS. Sloand et al. have shown that (oligo)-clonal $\mathrm{T}$ cell expansions are present in all trisomy 8 patients [8]. In our series, we analyzed PB of seven patients with trisomy 8 . Notwithstanding that all patients with trisomy 8 have been shown to have clonal $\mathrm{T}$ cell expansions and that these $\mathrm{T}$ cell expansions have been shown to have an effector phenotype [10], we could not demonstrate that this specific patient group had a higher prevalence of activated T cells, nor could we show that trisomy 8 patients consistently fell into the group with "high" expression of activation markers. It is not possible to draw definite conclusions from this, as we did not investigate skewing in the TCR Vbeta repertoire in these patients. Nevertheless, this observation is suggestive that immunophenotyping of all PB T cells is not a good surrogate method to identify patients with clonal effector $\mathrm{T}$ cell expansions.

Also the absence of suppressive activity of activated $\mathrm{T}$ cells on in vitro clonogenic growth questions the relevance of expression of these markers. We showed in 18 $\mathrm{BM}$ samples, that the number of CFU-GM and BFU-E grown was independent of the relative expression by $\mathrm{T}$ cells of the markers HLA-DR, CD28, CD57 and CD62L in that BM culture. This suggests that the mere activated state of lymphocytes, represented by expression of these markers does not reflect an inhibitory activity on in vitro hematopoiesis.

\section{Conclusions}

In summary, our current observations show that patients with MDS have similar numbers of $\mathrm{CD} 4^{+} \mathrm{T}$ cells and $\mathrm{CD} 8^{+}$ $\mathrm{T}$ cells compared to age controls, but they do have fewer NK and B cell numbers. We have additional evidence that $B$ cells and NK cells are clonally derived in a substantial part of patients. In addition, we show that $\mathrm{T}$ cell activation, represented by increased expression of HLA-DR and CD57 and decreased expression of CD28 and CD62L, is common in patients with MDS in PB as in BM. But their presence is not restricted to a specific clinical subgroup 
and together with the absence of in vitro myelosuppressive activity, our results indicate that immunophenotyping of PB T cells with these markers is not a good method to identify patients with a suspected immune-mediated disease.

\section{Acknowledgements}

This research was supported by grant OT/00/23 of the Research Council of the Catholic University of Leuven and grant G.0370.01 from the Research Foundation Flanders (FWO). The author S.M. is a research fellow, and the authors P.V. and M.D. are clinical professors of the FWO. We would like to thank Ms. Vicky Raets for her support with the flow cytometry and Mr. Viktor Van Duppen for performing the HUMARA experiments.

\section{References}

[1] Delforge M. Understanding the pathogenesis of myelodysplastic syndromes. Hematol J 2003;4:303-9.

[2] Hamblin TJ. Immunological abnormalities in myelodysplastic syndromes. Semin Hematol 1996;33:150-62.

[3] Selleri C, Maciejewski JP, Catalano L, Ricci P, Andretta C, Luciano L, et al. Effects of cyclosporine on hematopoietic and immune functions in patients with hypoplastic myelodysplasia. Cancer 2002;95:191122.

[4] Saunthararajah Y, Molldrem JJ, Rivera M, Williams A, StetlerStevenson M, Sorbara L, et al. Coincident myelodysplastic syndrome and T-cell large granular lymphocytic disease: clinical and pathophysiological features. Br J Haematol 2001;112:195-200.

[5] Molldrem JJ, Jiang YZ, Stetler-Stevenson M, Mavroudis D, Hensel N, Barrett AJ. Haematological response of patients with myelodysplastic syndrome to antithymocyte globulin is associated with a loss of lymphocyte-mediated inhibition of CFU-GM and alterations in T-cell receptor Vbeta profiles. Br J Haematol 1998;102:1314-22.

[6] Epperson DE, Nakamura R, Saunthararajah Y, Melenhorst JJ, Barrett AJ. Oligoclonal $\mathrm{T}$ cell expansion in myelodysplastic syndrome: evidence for an autoimmune process. Leuk Res 2001;25:1075-83.

[7] Melenhorst JJ, Eniafe R, Follmann D, Nakamura R, Kirby M, Barrett AJ. Molecular and flow cytometric characterization of the CD4 and CD8 T-cell repertoire in patients with myelodysplastic syndromes. $\mathrm{Br}$ J Haematol 2002;119:97-105.

[8] Sloand EM, Mainwaring L, Fuhrer M, Ramkissoon S, Risitano AM, Keyvanafar K, et al. Preferential suppression of trisomy 8 compared with normal hematopoietic cell growth by autologous lymphocytes in patients with trisomy 8 myelodysplastic syndrome. Blood 2005;106:841-51.

[9] Wlodarski MW, Gondek LP, Nearman ZP, Plasilova M, Kalaycio M, Hsi ED, et al. Molecular strategies for detection and quantitation of clonal cytotoxic T-cell responses in aplastic anemia and myelodysplastic syndrome. Blood 2006;108:2632-41.

[10] Epling-Burnette PK, Painter JS, Rollison DE, Ku E, Vendron D, Widen $\mathrm{R}$, et al. Prevalence and clinical association of clonal T-cell expansions in Myelodysplastic Syndrome. Leukemia 2007;21:659-67.

[11] Kook H, Zeng W, Guibin C, Kirby M, Young NS, Maciejewski JP. Increased cytotoxic $\mathrm{T}$ cells with effector phenotype in aplastic anemia and myelodysplasia. Exp Hematol 2001;29:1270-7.

[12] Aivado M, Rong A, Stadler M, Germing U, Giagounidis A, Strupp C, et al. Favourable response to antithymocyte or antilymphocyte globulin in low-risk myelodysplastic syndrome patients with a 'non-clonal' pattern of X-chromosome inactivation in bone marrow cells. Eur J Haematol 2002;68:210-6.

[13] Molldrem J, Caples M, Mavroudis D, Plante M, Young NS, Barrett AJ. Antithymocyte globulin (ATG) abrogates cytopenias in patients with myelodysplastic syndrome. Br J Haematol 1997;99:699-705.

[14] Tichelli A, Gratwohl A, Wuersch A, Nissen C, Speck B. Antilymphocyte globulin formyelodysplastic syndrome? Br J Haematol 1988;68:139-40.

[15] Broliden PA, Dahl IM, Hast R, Johansson B, Juvonen E, Kjeldsen L, et al. Antithymocyte globulin and cyclosporine A as combination therapy for low-risk non-sideroblastic myelodysplastic syndromes. Haematologica 2006;91:667-70.

[16] Saunthararajah Y, Nakamura R, Wesley R, Wang QJ, Barrett AJ. A simple method to predict response to immunosuppressive therapy in patients with myelodysplastic syndrome. Blood 2003;102:3025-7.

[17] Saunthararajah Y, Nakamura R, Nam JM, Robyn J, Loberiza F, Maciejewski JP, et al. HLA-DR15 (DR2) is overrepresented in myelodysplastic syndrome and aplastic anemia and predicts a response to immunosuppression in myelodysplastic syndrome. Blood 2002;100:1570-4.

[18] Delforge M, Demuynck H, Vandenberghe P, Verhoef G, Zachee P, van Duppen $\mathrm{V}$, et al. Polyclonal primitive hematopoietic progenitors can be detected in mobilized peripheral blood from patients with high-risk myelodysplastic syndromes. Blood 1995;86:3660-7.

[19] Lyon MF. Gene action in the X-chromosome of the mouse (Mus musculus L.). Nature 1961;190:372-3.

[20] Van den Hove LE, Symons F, Vandenberghe P, Verhoef GE, Demuynck $\mathrm{H}$, Van Gool SW, et al. Multivariate reconstruction of lymphocyte profiles in a two-dimensional graphical model as a tool for the investigation of lymphocyte subset distribution in health and disease. Cytometry 1997;28:220-7.

[21] Bynoe AG, Scott CS, Ford P, Roberts BE. Decreased T helper cells in the myelodysplastic syndromes. Br J Haematol 1983;54:97-102.

[22] Colombat PH, Renoux M, Lamagnere J-P, Renoux G. Immunologic indices in myelodysplastic syndromes. Cancer 1988;61:1075-81.

[23] Symeonidis A, Kourakli A, Katevas P, Perraki M, Tiniakou M, Matsouka $\mathrm{P}$, et al. Immune function parameters at diagnosis in patients with myelodysplastic syndromes: correlation with the FAB classification and prognosis. Eur J Haematol 1991;47:277-81.

[24] Baumann I, Scheid C, Koref MS, Swindell R, Stern P, Testa NG. Autologous lymphocytes inhibit hemopoiesis in long-term cultures in patients with myelodysplastic syndromes. Exp Hematol 2002;30:1405-11.

[25] Molldrem J, Rivera M, Bahceci E. Treatment of bone marrow failure of myelodysplastic syndrome with antithymocyte globulin. Ann Intern Med 2002;137:156-63.

[26] Shimamoto T, Tohyama K, Okamoto T. Cyclosporin A therapy for patients with myelodysplastic syndrome: multicenter pilot studies in Japan. Leuk Res 2003;27:783-8.

[27] Barrett J, Sloand E, Young N. Determining which patients with myelodysplastic syndrome will respond to immunosuppressive treatment. Haematologica 2006;91:583-4.

[28] Amin HM, Jilani I, Estey EH, Keating MJ, Dey AL, Manshouri T, et al. Increased apoptosis in bone marrow B lymphocytes but not $\mathrm{T}$ lymphocytes in myelodysplastic syndrome. Blood 2003;102:1866-8.

[29] Champion KM, Gilbert JG, Asimakopoulos FA, Hinshelwood S, Green AR. Clonal haemopoiesis in normal elderly women: implications for the myeloproliferative disorders and myelodysplastic syndromes. Br J Haematol 1997;97:920-6.

[30] Prchal JT, Throckmorton DW, Carroll 3rd AJ, Fuson EW, Gams RA, Prchal JF. A common progenitor for human myeloid and lymphoid cells. Nature 1978;274:590-1.

[31] Tefferi A, Thibodeau SN, Solberg Jr LA. Clonal studies in the myelodysplastic syndrome using X-linked restriction fragment length polymorphisms. Blood 1990;75:1770-3.

[32] Culligan DJ, Cachia P, Whittaker J, Jacobs A, Padua RA. Clonal lymphocytes are detectable in only some cases of MDS. Br J Haematol 1992;81:346-52. 
[33] Okada M, Okamoto T, Takemoto Y, Kanamaru A, Kakishita E. Function and $\mathrm{X}$ chromosome inactivation analysis of $\mathrm{B}$ lymphocytes in myelodysplastic syndromes with immunological abnormalities. Acta Haematol 1999;102:124-30.

[34] Tsukamoto N, Morita K, Maehara T, Okamoto K, Karasawa M, Omine M, Naruse T. Clonality in myelodysplastic syndromes: demonstration of pluripotent stem cell origin using X-linked restriction fragment length polymorphisms. Br J Haematol 1993;83:589-94.

[35] Abrahamson G, Boultwood J, Madden J, Kelly S, Oscier DG, Rack K et al. Clonality of cell populations in refractory anaemia using combined approach of gene loss and X-linked restriction fragment length polymorphism-methylation analyses. Br J Haematol 1991;79:550-5.

[36] Anan K, Ito M, Misawa M, Ohe Y, Kai S, Kohsaki M, et al. Clonal analysis of peripheral blood and haemopoietic colonies in patients with aplastic anaemia and refractory anaemia using the polymorphic short tandem repeat on the human androgen-receptor (HUMARA) gene. $\mathrm{Br}$ J Haematol 1995;89:838-44.

[37] Van Kamp H, Fibbe W, Jansen R, Vander Keur M, De Graaff E, Willemze R, et al. Clonal involvement of granulocytes and monocytees, but not of $\mathrm{T}$ and B lymphocytes and natural killer cells in patients with myelodysplasia: analysis of X-linked restriction fragment length polymorphisms and polymerase chain reaction of the phophoglycerate kinase gene. Blood 1992;80:1774-80.

[38] Delforge M, Demuynck H, Verhoef G, Vandenberghe P, Zachee P, Maertens J, et al. Patients with high-risk myelodysplastic syndrome can have polyclonal or clonal haemopoiesis in complete haematological remission. Br J Haematol 1998;102:486-94.

[39] Boultwood J, Wainscoat J. Clonality in the myelodysplastic syndromes. Int J Hematol 2001;73:411-5.

[40] Lazuardi L, Jenewein B, Wolf AM, Pfister G, Tzankov A, GrubeckLoebenstein B. Age-related loss of naive T cells and dysregulation of T-cell/B-cell interactions in human lymph nodes. Immunology 2005; 114:37-43.

[41] Sternberg A, Killick S, Littlewood T, Hatton C, Peniket A, Seidl T, et al. Evidence for reduced B-cell progenitors in early (low-risk) myelodysplastic syndrome. Blood 2005;106:2982-91.

[42] Tajima F, Kawatani T, Endo A, Kawasaki H. Natural killer cell activity and cytokine production as prognostic factors in adult acute leukemia. Leukemia 1996;10:478-82.

[43] Aw D, Silva AB, Palmer DB. Immunosenescence: emerging challenges for an ageing population. Immunology 2007;120:435-46.

[44] Fujii S, Shimizu K, Klimek V, Geller MD, Nimer SD, Dhodapkar MV. Severe and selective deficiency of interferon-gamma-producing invariant natural killer $\mathrm{T}$ cells in patients with myelodysplastic syndromes. Br J Haematol 2003;122:617-22.

[45] Ogata K, Fujii H, Yokose N, An E, Tamura H, Kamikubo K, et al. Defective natural killer (NK) cell-mediated cytotoxicity does not imply clonal involvement of $\mathrm{NK}$ cells in myelodysplastic syndromes. $\mathrm{Br} \mathrm{J}$ Haematol 1994;87:396-8.

[46] Kiladjian JJ, Bourgeois E, Lobe I, Braun T, Visentin G, Bourhis JH, et al. Cytolytic function and survival of natural killer cells are severely altered in myelodysplastic syndromes. Leukemia 2006;20:46370.

[47] Ling M, Delforge M, van Duppen V, Verhoef G, Emanuel B, Boogaerts $\mathrm{M}$, et al. Circulating myeloid and lymphoid precursor dendritic cells are clonally involved in myelodysplastic syndromes. Leukemia 2004;18:1451-6.

[48] Miura I, Kobayashi Y, Takahashi N, Saitoh K, Miura A. Involvement of natural killer cells in patients with myelodysplastic syndrome carrying monosomy 7 revealed by the application of fluorescence in situ hybridization to cells collected by means of fluorescence-activated cell sorting. Br J Haematol 2000;110:876-9. 